Original Research Paper

\title{
Sosialisasi Pemanfaatan TOGA Dan Pembuatan Sabun Batang Alami (Sabun Aloe vera) Kepada Murid Yayasan Generasi Muslim Cendekia di Lombok Tengah, Indonesia
}

\author{
Anggit L. Sunarwidhi ${ }^{1 *}$, Dyke Gita Wirasisya ${ }^{1}$, Nisa Isneni Hanifa ${ }^{1}$ \\ ${ }^{1}$ Program Studi Farmasi, Fakultas Kedokteran, Universitas Mataram, Mataram, Indonesia
}

DOI: https://doi.org/10.29303/jpmpi.v3i2.513

Sitasi : Sunarwidhi, A. L., Wirasisya, D. K., \& Hanifa, N. I. (2020). Sosialisasi Pemanfaatan TOGA Dan Pembuatan Sabun Batang Alami (Sabun Aloe vera) Kepada Murid Yayasan Generasi Muslim Cendekia di Lombok Tengah, Indonesia. Jurnal Pengabdian Magister Pendidikan IPA, 3(2)

\author{
Article history \\ Received: 28 Oktober 2020 \\ Revised: 10 Nopember 2020 \\ Accepted: 27 Nopemeber 2020 \\ *Corresponding Author: \\ Anggit L. Sunarwidhi, \\ Program Studi Farmasi, \\ Universitas Mataram, Mataram, \\ Indonesia \\ Email: \\ anggit.sunarwidhi@unram.ac.id
}

\section{Pendahuluan}

Indonesia merupakan rumah dari 30000 tanaman dari 40000 total jenis tumbuhan obat di dunia. Meskipun jumlah tanaman obat di Indonesia begitu besar namun tanamantanaman ini belum dimanfaatkan secara maksimal oleh masyarakat Indonesia. Pemanfaatan tumbuhan sebagai obat bukan hal yang baru dan telah lama dikembangkan di

\begin{abstract}
Yayasan Generasi Muslim Cendekia (Yayasan GMC) terletak di desa Puyung, Lombok Tengah, Indonesia, dan telah memiliki fasilitas TOGA, namun selama ini tumbuh-tumbuhan obat yang terdapat di fasilitas tersebut tidak dimanfaatkan secara maksimal. Minimnya pengetahuan murid yayasan GMC yang menjadi alasan terjadinya hal tersebut. Oleh karena itu, dibutuhkan suatu program sosialisasi untuk mengedukasi murid di yayasan tersebut terkait hal ini. Selain itu, program sosialisasi juga melibatkan praktek pembuatan sediaan sederhana dengan pemanfaatan tanaman obat, yaitu pembuatan sabun batang alami dengan menggunakan aloe vera sebagai bahan utamanya. Sabun ini sangat bermanfaat terutama di masa pandemi COVID-19. Hasil evaluasi kegiatan menunjukkan bahwa kegiatan sosialisasi ini telah berjalan dengan baik, ditunjukkan dengan adanya peningkatan nilai posttest peserta yang signifikan dibandingkan dengan nilai pretest peserta. Melalui kegiatan ini, peserta mendapatkan pengetahuan terkait pemanfaatan TOGA maupun cara pembuatan sabun bantang alami (sabun aloe vera). Peserta menunjukkan antusias yang tinggi pada saat praktek maupun diskusi. Diharapkan ke depannya sosialisasi seperti ini dapat terus berlanjut, sehingga dapat terus meningkatkan kreatifitas murid-murid yayasan GMC dalam pemanfaatan TOGA, yang tidak hanya bermanfaat untuk kesehatan tetapi juga dapat berpotensi meningkatkan taraf ekonomi warga desa tersebut.
\end{abstract}

Keywords: Sosialisasi TOGA, Sabun batang alami, Aloe vera, Desa Puyung

Indonesia (Zuhud, 2011). Namun, masih banyak warga di daerah pelosok dengan tingkat ekonomi rendah yang masih tidak memanfaatkan tumbuhan obat meskipun ekosistem di daerahnya sangat mendukung. Penelitian menunjukkan bahwa hal ini dapat disebabkan oleh keterpencilan daerah dan kesulitan akses pasar (Byg and Balslev., 2001, Ladio and Lozada, 2001, Torre et al., 2012). Penelitian lain juga mengkonfirmasi bahwa 
infrastruktur dan faktor ekonomi merupakan salah satu penyebab minimnya jumlah spesies tumbuhan obat yang digunakan masyarakat (Pratiwi et al., 2017). Hal ini sangat disayangkan mengingat pengetahuan tentang pembuatan tanaman obat keluarga (TOGA) serta pemanfaatnya akan sangat berguna bagi warga di daerah. Tidak hanya untuk pengobatan dan kesehatan keluarga tetapi informasi tersebut dapat juga digunakan untuk meningkatkan perekomian warga, mengingat harga obat kimiawi yang masih terbilang tinggi, sehingga penggunaan tumbuhan obat bisa menjadi alternatif pengobatan. Seperti yang telah dilakukan oleh warga di daerah lain di Indonesia (Mahendra, 2005). Yayasan Generasi Muslim Cendekia (GMC) yang terletak di Desa Puyung Lombok Tengah Indonesia telah memiliki fasilitas TOGA yang berisi tanaman-tanaman obat. Berdasarkan hasil wawancara dengan salah satu pengurus yayasan GMC, tanaman obat yang dibudidayakan oleh yayasan GMC adalah kunyit, sereh, lengkuas, kencur, lidah buaya, kumis kucing, katuk, pecut kuda, lidah mertua, pletekan, tapak dara, kelor, kemangi, jeruk nipis, jahe merah, sambiloto, dan tanaman sirih hijau. Namun, murid yayasan GMC tidak begitu memiliki pengetahuan tentang bagaimana pemanfaatan TOGA secara maksimal. Hal inilah yang memicu dibutuhkannya sosialisasi tentang pemanfaatan TOGA. Program sosialisasi ini juga melibatkan praktek pembuatan sediaan tradisional sederhana yaitu pembuatan sabun batang alami yang sangat berguna terutama untuk masa pandemi Coronavirus disease-19 (COVID-19). Sejak outbreak pertama sampai saat jurnal ini ditulis, belum ada obat maupun vaksin yang spesifik untuk menanggulangi penyakit COVID-19 ini, sehingga menjaga kebersihan dengan mencuci tangan secara rutin menjadi salah satu anjuran untuk mencegah penyebaran penyakit ini. Namun mencuci tangan dengan sabun kimiawi maupun hand sanitizer berbasis alkohol menyebabkan beberapa kerugian pada kesehatan kulit pengguna maupun kerugian terhadap lingkungan, sehingga penggunaan sabun alami menjadi alternatif yang cukup menarik perhatian. Selain proses pembuatannya yang murah dan mudah, sabun alami ini dapat juga mengurangi penggunaan bahan-bahan kimiawi yang biasa terdapat di dalam sabun komersiil, sehingga bisa mengurangi efek samping terhadap kesehatan kulit maupun juga dapat menghasilkan produk yang lebih ramah lingkungan. Tumbuhan yang terdapat di TOGA yang dapat dimanfaatkan sebagai bahan aktif sabun batang alami adalah lidah buaya atau aloe vera.

Aloe vera adalah salah satu tanaman yang terdapat di Indonesia yang banyak sekali dimanfaatkan untuk kesehatan termasuk kesehatan kulit (Ariyani and Hidayati, 2018). Aloe vera termasuk ke dalam keluarga tanaman Liliaceae dan bentuk tanaman ini mirip seperti kaktus. Aloe vera terdiri dari dua bagian, yaitu bagian daun dan gel bening (Gambar 1). Gel aloe vera terdiri dari $99.3 \%$ air dan $0.7 \%$ komponen senyawa aktif (A. et al., 2008). $0.7 \%$ bagian dari gel ini mengandung kurang lebih 75 komponen aktif termasuk polisakarida, vitamin, enzim, mineral, gula, lignin, saponin, asam salisilat, dan asam amino (Volger and Ernst, 1999, Nejatzadeh-Barandozi, 2013, Hashemi et al., 2015). Aloe vera memiliki beberapa khasiat termasuk antiinflamasi, antioxidant, antidiabetes dan juga dapat digunakan dalam pengobatan luka. Beberapa penelitian juga telah menunjukkan bahwa aloe vera dapat digunakan sebagai antibakteri (Goud et al., 2018), maupun antivirus (Maan et al., 2018, Mpiana et al., 2020). Kemampuan ekstrak ethanol antibakteri aloe vera ini telah diamati pada beberapa strain bakteri termasuk Staphylococcus aureus, Pseudomonas aeruginosa, Escherichia coli dan Klebsiella pneumonia (Haque et al., 2019). Sedangkan gel aloe vera telah dilaporkan dapat menghentikan pertumbuhan isolat-isolat bakteri Pseudomonas aeruginosa yang didapat dari infeksi luka bakar, sehingga aloe vera dinyatakan dapat digunakan sebagai alternatif pencegahan infeksi bakteri pada luka bakar (Goudarzi et al., 
2015). Selain itu, aloin dan aloe-emodin di dalam aloe vera dinyatakan mampu membunuh envelope virus termasuk SARS-COV-1, influenza, dan HIV dengan merusak lapisan lipid dari virus maupun menghambat replikasi virus (Mpiana et al., 2020). Data-data penelitian tersebut menjadi dasar dipilihnya gel aloe vera sebagai bahan aktif untuk pembuatan sabun batang alami di dalam kegiatan pengabdian masyarakat ini.

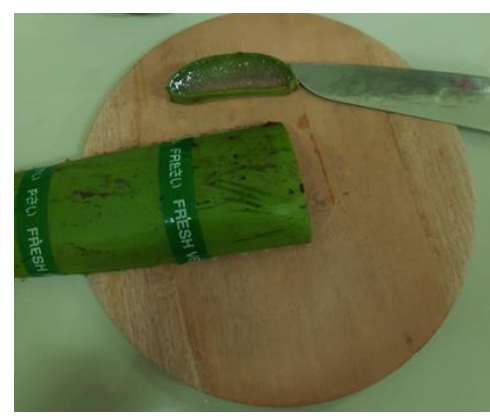

Gambar 1. Lidah buaya (Aloe vera) : daun dan gel bening

\section{Metode}

Kegiatan pengabdian ini dilaksanakan di Yayasan Generasi Muslim Cendekia (Yayasan GMC) yang terletak di Desa Puyung, Lombok Tengah, Indonesia. Peserta kegiatan ini adalah murid SMK maupun guru jurusan teknologi pangan yayasan GMC. Kegiatan ini dilakukan oleh dosen-dosen bidang ahli biologi farmasi dengan beberapa mahasiswa Program Studi Farmasi Fakultas Kedokteran Universitas Mataram.

Kegiatan ini terdiri dari dua tahap: Tahap pertama berupa sosialisasi pemanfaatan TOGA kepada murid yayasan GMC. Kemudian tahap kedua dari kegiatan ini adalah praktek pembuatan sabun batang alami (sabun aloe vera) (Gambar 2).

Tahapan pertama yang berupa sosialisasi diawali dengan pelaksanaan pretest, yang dilanjutkan dengan pemberian sosialisasi. Metode pelaksanaan sosialisasi yang digunakan berupa metode ceramah termasuk pembagian brosur (leaflet) tentang TOGA.
Tahap kedua dilaksanakan dengan pelaksanaan demo pembuatan sabun batang alami dengan bahan aktif (bahan utama) berupa daun aloe vera. Praktek pembuatan sabun dilaksanakan oleh staff dosen bidang ahli biologi farmasi dan mahasiswa Prodi Farmasi Fakultas Kedokteran Universitas Mataram. Demo pembuatan sabun ini juga sekaligus melibatkan praktek langsung oleh murid yayasan GMC. Murid diberi kesempatan untuk mencoba langsung pembuatan sabun alami ini.

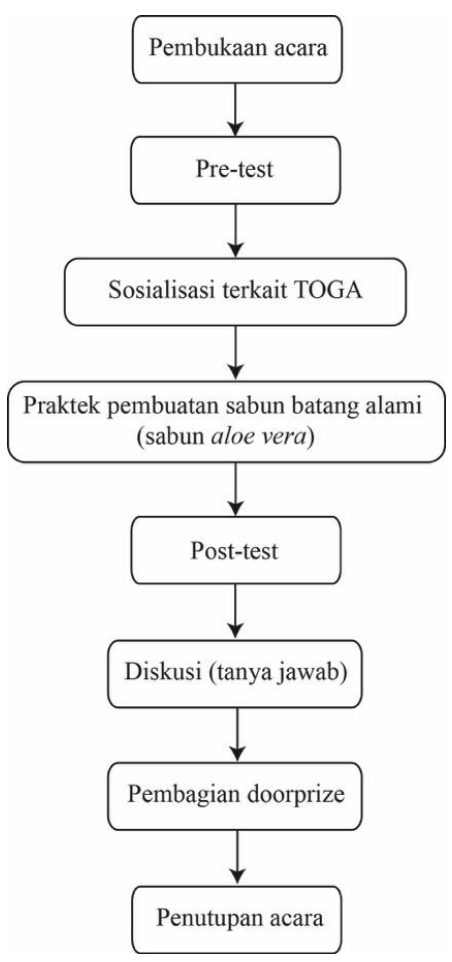

Gambar 2. Skema alur pelaksanaan kegiatan pengabdian masyarakat sosialisasi pemanfaatan TOGA dan pembuatan sabun antibakteri alami

Pada pembuatan sabun alami ini diperlukan waktu pengerasan sabun selama 18 jam, sehingga masing-masing peserta diberi sabun di dalam cetakan individual sehingga setiap peserta dapat membawa pulang hasil sabun yang telah dibuat. Setelah pemberian materi sosialisasi dan praktek pembuatan sabun, kemudian kegiatan ini diakhiri dengan posttest untuk melihat keberhasilan sosialisasi. Pada akhir kegiatan ini dilakukan sesi tanya 
jawab dan pembagian doorprize untuk peserta yang paling aktif.

Evaluasi kegiatan dilakukan dengan melihat nilai pretest dan posttest peserta, kemudian dilakukan analisis statistika paired $t$ test terhadap data yang diperoleh.

\section{Hasil dan Pembahasan}

Kegiatan pengabdian masyarakat ini dilaksanakan di Yayasan GMC Lombok Tengah, Indonesia. Kegiatan ini dilakukan dengan tujuan untuk meningkatkan pengetahuan murid-murid di Yayasan GMC terkait pemanfaatan TOGA. Salah satu pemanfaatan TOGA yang dipraktekkan pada kesempatan kali ini adalah pembuatan sabun batang alami yang memanfaatkan salah satu tanaman yang banyak ditemukan di TOGA pekarangan rumah tangga di Indonesia, yaitu lidah buaya (aloe vera).

Kegiatan ini dilaksanakan pada masa pandemi COVID-19, sehingga pelaksanaan kegiatan menerapkan protokol kesehatan COVID-19, antara lain seluruh peserta dan panitia wajib menggunakan masker, disediakannya hand sanitizer saat acara, dan adanya pembatasan jumlah peserta yaitu 14 orang peserta. Setelah melakukan diskusi dengan pihak sekolah dan yayasan, kemudian diputuskan kegiatan dihadiri oleh murid SMK jurusan teknologi pangan sejumlah 12 orang didampingi oleh 2 orang guru (Gambar 3).

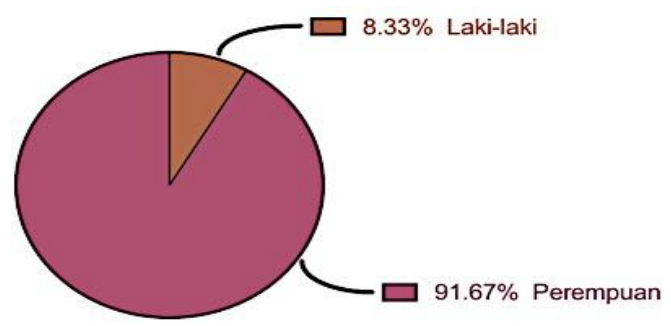

Gambar 3. Variasi peserta kegiatan sosialisasi TOGA dan pembuatan sabun alami di Yayasan GMC, Lombok Tengah, Indonesia.

Pelaksanan rangkaian kegiatan pengabdian ini dimulai dengan pelaksanaan pretest untuk mengukur sejauh mana pengetahuan peserta akan pemanfaatan TOGA, kemudian diikuti dengan penyuluhan pertama yaitu terkait penjelasan pemanfaatan TOGA (Gambar 4). Masing-masing peserta juga mendapatkan brosur (leaflet) terkait beberapa TOGA yaitu aloe vera, jeruk merah, sambiloto, dan jeruk nipis. Setelah pemberian materi, dilanjutkan ke rangkaian acara berikutnya yaitu penjelasan dan praktek pembuatan sabun batang alami. Setiap peserta diberikan brosur (leaflet) berisi protokol pembuatan sabun alami aloe vera.

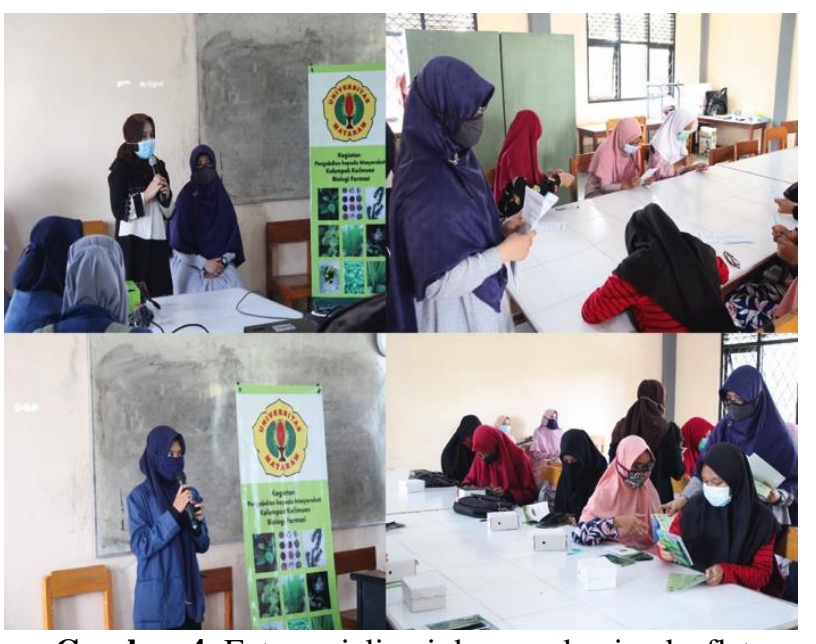

Gambar 4. Foto sosialisasi dan pembagian leaflet tentang pemanfaatan TOGA

Pembuatan sabun dilakukan dengan metode melt and pour dengan menggunakan sabun basis gliserin serta bahan aktif yang digunakan adalah gel aloe vera (Gambar 5). Gliserin pada sabun berperan sebagai pelembab. Sabun basis gliserin dilelehkan terlebih dahulu dengan metode kukus untuk menghindari terjadinya burning dari basis sabun yang dapat mengurangi estetika sabun dan menyebabkan basis menjadi warna kecokelatan. Setelah basis sabun leleh sempurna, kemudian basis didinginkan dan dilanjutkan dengan persiapan gel aloe vera.

Gel aloe vera disiapkan secara langsung di lokasi acara. Hal ini agar peserta dapat mengetahui cara menyiapkan gel aloe vera alami dari daun aloe vera, sehingga tidak perlu membeli gel aloe vera komersiil. 
Gel yang telah siap kemudian diberi minyak zaitun dan dicampurkan ke basis gel bersamaan dengan essential oil yang berperan sebagai pengharum sabun. Pada saat acara, ada 2 jenis essential oil yang disediakan oleh panitia acara yaitu sandalwood dan orange. Peserta diberi kesempatan untuk memilih sendiri pengharum yang ingin digunakan.

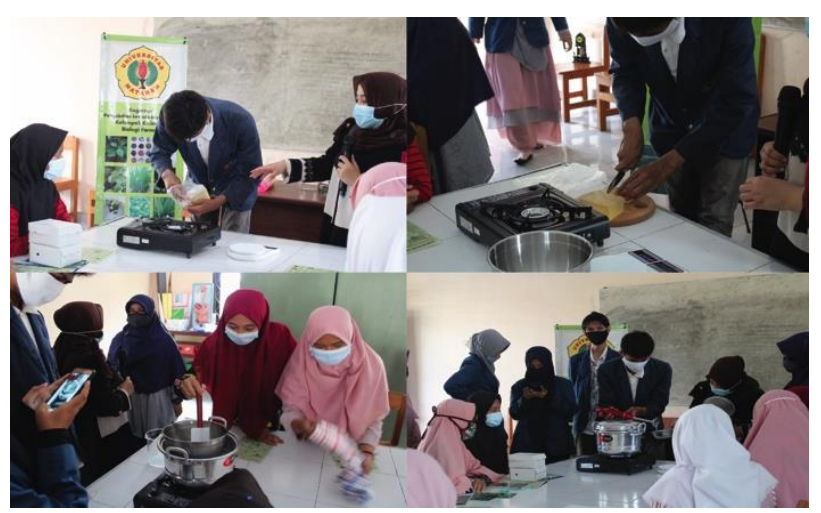

Gambar 5. Foto praktek pembuatan sabun antibakteri alami aloe vera

Campuran sabun yang telah siap kemudian dituang ke dalam cetakan sabun dan sabun harus didiamkan di dalam cetakan selama minimal 18 jam untuk mengeras. Cetakan yang disediakan berupa cetakan individual, sehingga setiap peserta memiliki kesempatan untuk membawa pulang satu sabun yang telah dibuat (Gambar 6). Setelah praktek pembuatan sabun, dilanjutkan dengan posttest untuk mengevaluasi dan menilai keberhasilan kegiatan.

Agenda terakhir pada kegiatan ini adalah sesi tanya jawab. Peserta diberi kesempatan untuk bertanya terkait materi yang telah diberikan kepada staff dosen. Pada sesi ini, peserta sangat aktif dalam memberikan pertanyaan kepada pemateri. Ini menunjukkan adanya antusiasme dari peserta untuk mengembangkan produk ini lebih lanjut.

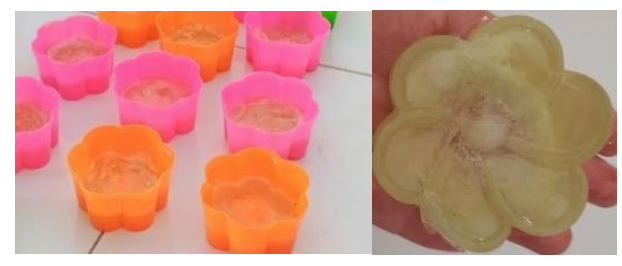

Gambar 6. Sabun batang alami (Sabun aloe vera)

Hasil evaluasi kegiatan yang dilakukan dengan melaksanakan pretest dan posttest menunjukkan bahwa terjadi peningkatan nilai posttest peserta yang signifikan dibandingkan dengan nilai pretest peserta (Gambar 7). Hal ini mengindikasikan keberhasilan sosialisasi, dan peserta mendapatkan pengetahuan tambahan terkait pemanfaatan TOGA maupun pembuatan sabun batang alami (sabun aloe vera).

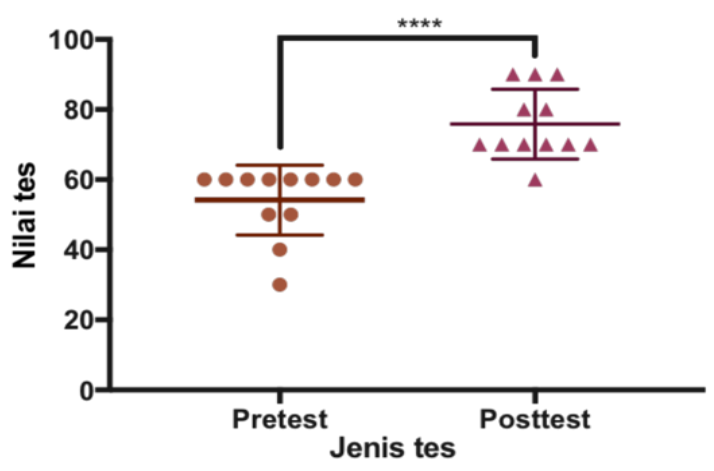

Gambar 7. Hasil evaluasi kegiatan sosialisasi pemanfaatan TOGA di Yayasan GMC, Lombok Tengah. Uji statistika paired t-test $(\mathrm{n}=12, \mathrm{p}<0.0001)$.

\section{Kesimpulan}

Kesimpulan yang dapat ditarik dari kegiatan ini adalah sosialisasi pemanfaatan TOGA ini telah dilakukan di Yayasan GMC, Lombok Tengah, Indonesia dengan baik. Kegiatan ini tidak hanya meningkatkan pengetahuan murid-murid di yayasan GMC, namun juga dapat menjadi suatu alternatif untuk peningkatan ekonomi masyarakat sekitar yaitu dengan pembuatan sabun batang alami yang sangat bermanfaat terutama di masa pandemi COVID-19, di mana dituntut untuk selalu menjaga kebersihan dengan mencuci tangan menggunakan sabun untuk mencegah penyebaran penyakit ini.

\section{Saran}

Dikarenakan kegiatan ini dilakukan pada masa pandemi COVID-19, sehingga 
kuota peserta sangat terbatas. Diharapkan kegiatan selanjutnya dapat menjangkau audience yang lebih luas yaitu dengan dilakukan peningkatkan jumlah maupun variasi peserta.

\section{Ucapan Terima Kasih}

Penulis mengucapkan terima kasih kepada semua pihak yang terlibat dalam kegiatan sosialisai ini, yaitu meliputi pihak sekolah dan yayasan Generasi Muslim Cendekia (yayasan GMC), mahasiswa maupun dosen-dosen Program Studi Farmasi Fakultas Kedokteran, Universitas Mataram. Penulis juga mengucapkan terima kasih kepada DIPA BLU (PNBP) Universitas Mataram yang telah membiayai kegiatan pengabdian masyarakat ini.

\section{Daftar Pustaka}

A., S., Vasani, R. \& Saple, D. 2008. Aloe vera: a short review. . Indian Journal of Dermatology., 53, 163-166.

Ariyani, S. \& Hidayati. 2018. Penambahan gel lidah buaya sebagai antibakteri pada sabun mandi cair berbahan dasar minyak kelapa. Jurnal Industri Hasil Perkebunan, 13, 1118.

Byg, A. \& Balslev. 2001. Diversity and use of palms in Zaharnena, eastern Madagascar. Biodiversity and Conservation., 10, 951970.

Goud, S., Aravelli, S., Dronamraju, S., Cherukui, G. \& Morishetty, P. 2018. Comparative evaluation of the antibacterial efficacy of aloe vera, $3 \%$ sodium hypochlorite, and $2 \%$ chlorhexidine gluconate againts enterococcus faccalis: an in vitro study. Cureus, 10.

Goudarzi, M., Fazeli, M., Azad, M., Seyedjavadi, S. \& Mousavi, R. 2015. Aloe vera gel: Effective therapeutic agent againts multidrug-resistant pseudomonas aeruginosa isolates recovered from burn wound infections. Chemoteraphy Research and Practice.

Haque, S., Saha, S., Salma, U., Nishi, M. \& Rahaman, M. 2019. Antibacterial effect of Aloe vera (Aloe barbadensis) leaf gel againts Staphylococcus aureus, Pseudomonas aeruginosa, Escherichia coli and Klebsiella pneumoniae. Mymensingh Medical Journal, 28, 490-496.

Hashemi, S., Madani, S. \& Abediankenari, S. 2015. The review on properties of Aloe vera in healing of cutaneous wounds. BioMed Research International.

Ladio, A. \& Lozada, M. 2001. Nontimber forest productase in two human populations from Northwest Patagonia: a quantitative approach. Human Ecology, 29, 367-380.

Maan, A. A., Nazir, A., Khan, M. K. I., Ahmad, T., Zia, R., Murid, M., \& Abrar, M. 2018. The therapeutic properties and applications of Aloe vera: A review. Journal of Herbal Medicine, 12, 1-10.

Mahendra, B. 2005. Jenis tanaman obat ampuh. Penebar swadaya.

Mpiana, P. T., Tshibangu, D. S., Kilembe, J. T., Gbolo, B. Z., Mwanangombo, D. T., Inkoto, C. L., ... \& Tshilanda, D. D. 2020. Aloe vera (L.) Burm. F. as a Potential AntiCOVID-19 Plant: A Mini-review of Its Antiviral Activity. European Journal of Medicinal Plants, 86-93.

Nejatzadeh-Barandozi. 2013. Antibacterial activities and antioxidant capacity of Aloe vera. Organic and Medicinal Chemistry Letters, 3, 1-8.

Pratiwi, F., Zuhud, E. \& Herdiyeni, Y. 2017. Metaanalysis jumlah spesies tumbuhan obat yang digunakan berdasarkan karakteristik faktor sosial ekonomi, lingkungan, dan geografis. Media Konservasi, 22, 64-70.

Torre, D. I., Ceron, C., Balslev \& Borchsenius, F. 2012. A biodiversity informatics approach to etnobotany: meta-analysis of plants use patterns in Ecuador. Ecology and Society., $17,115$.

Volger, B. \& Ernst, E. 1999. Aloe vera: A systematic review of its clinical effectiveness. British Journal of General Practice, 49, 823-8.

Zuhud, E. 2011. Potensi hutan tropika Indonesia sebagai penyangga bahan obat alam untuk kesehatan bangsa. 